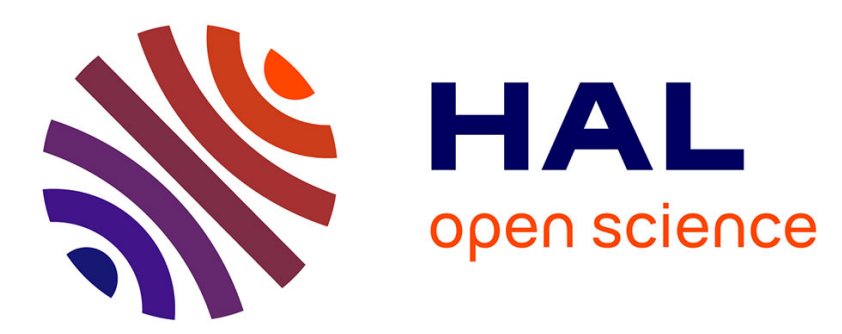

\title{
Important determinants to take into account to optimize protein nutrition in the elderly: solutions to a complex equation
}

Dominique Dardevet, Laurent Mosoni, Isabelle Savary-Auzeloux, Marie-Agnès Peyron, Sergio Polakof, Didier Remond

\section{To cite this version:}

Dominique Dardevet, Laurent Mosoni, Isabelle Savary-Auzeloux, Marie-Agnès Peyron, Sergio Polakof, et al.. Important determinants to take into account to optimize protein nutrition in the elderly: solutions to a complex equation. Proceedings of the Nutrition Society, 2021, 80 (2), pp.207-220. 10.1017/S0029665120007934 . hal-03032902

\section{HAL Id: hal-03032902 https://hal.inrae.fr/hal-03032902}

Submitted on 25 Nov 2021

HAL is a multi-disciplinary open access archive for the deposit and dissemination of scientific research documents, whether they are published or not. The documents may come from teaching and research institutions in France or abroad, or from public or private research centers.
L'archive ouverte pluridisciplinaire HAL, est destinée au dépôt et à la diffusion de documents scientifiques de niveau recherche, publiés ou non, émanant des établissements d'enseignement et de recherche français ou étrangers, des laboratoires publics ou privés. 


\section{Important determinants to take into account to optimize protein nutrition in the elderly: solutions to a complex equation}

Dardevet Dominique ${ }^{1}$, Mosoni Laurent ${ }^{1}$, Savary-Auzeloux Isabelle ${ }^{1}$, Peyron Marie-Agnès ${ }^{1}$, Polakof Sergio ${ }^{1}$, Rémond Didier ${ }^{1}$.

1 , Université Clermont Auvergne, INRAE, UMR1019, Unité Nutrition Humaine, Clermont-Ferrand 63000, France

Shortened version of the title:

Determinants of optimized protein nutrition with age

Key words:

Dietary proteins, matrix effect, energy supply, digestion speed, oral health 


\begin{abstract}
During aging, skeletal muscle develops anabolic resistance towards the stimulation of protein synthesis induced by dietary amino acids. The stimulation of muscle protein synthesis after food intake remains insufficient, even with a protein intake recommended for healthy adults. This alteration is one of the mechanisms known to be responsible for the decrease of muscle mass and function during aging, namely sarcopenia. Increasing dietary protein intake above the current recommended dietary allowances $(\mathrm{RDA}=0.83 \mathrm{~g} / \mathrm{kg} / \mathrm{d}$ ) has been strongly suggested to overcome the anabolic resistance observed. It is also specified that the dietary protein ingested should be of good quality. A protein of good quality is a protein whose amino acid (AA) composition covers the requirement of each AA when ingested at the RDA. However, the biological value of proteins may vary among dietary sources in which AA composition could be unbalanced. In the present review, we suggest that the quality of a dietary protein is also related to several other determinants. These determinants include the speed of digestion of dietary proteins, the presence of specific AAs, the food matrix in which the dietary proteins are included, the processes involved in the production of food products (milk gelation and cooking temperature), the energy supply and its nature, and the interaction between nutrients before ingestion. Particular attention is given to plant proteins for the nutrition of the elderly. Finally, the timing of protein intake and its association with the desynchronized intake of energetic nutrients is discussed
\end{abstract}




\section{Graphical Abstract}

\section{Optimizing protein intake in older adults should be a multi modal approach taking into account much more than just the amount of protein intake}

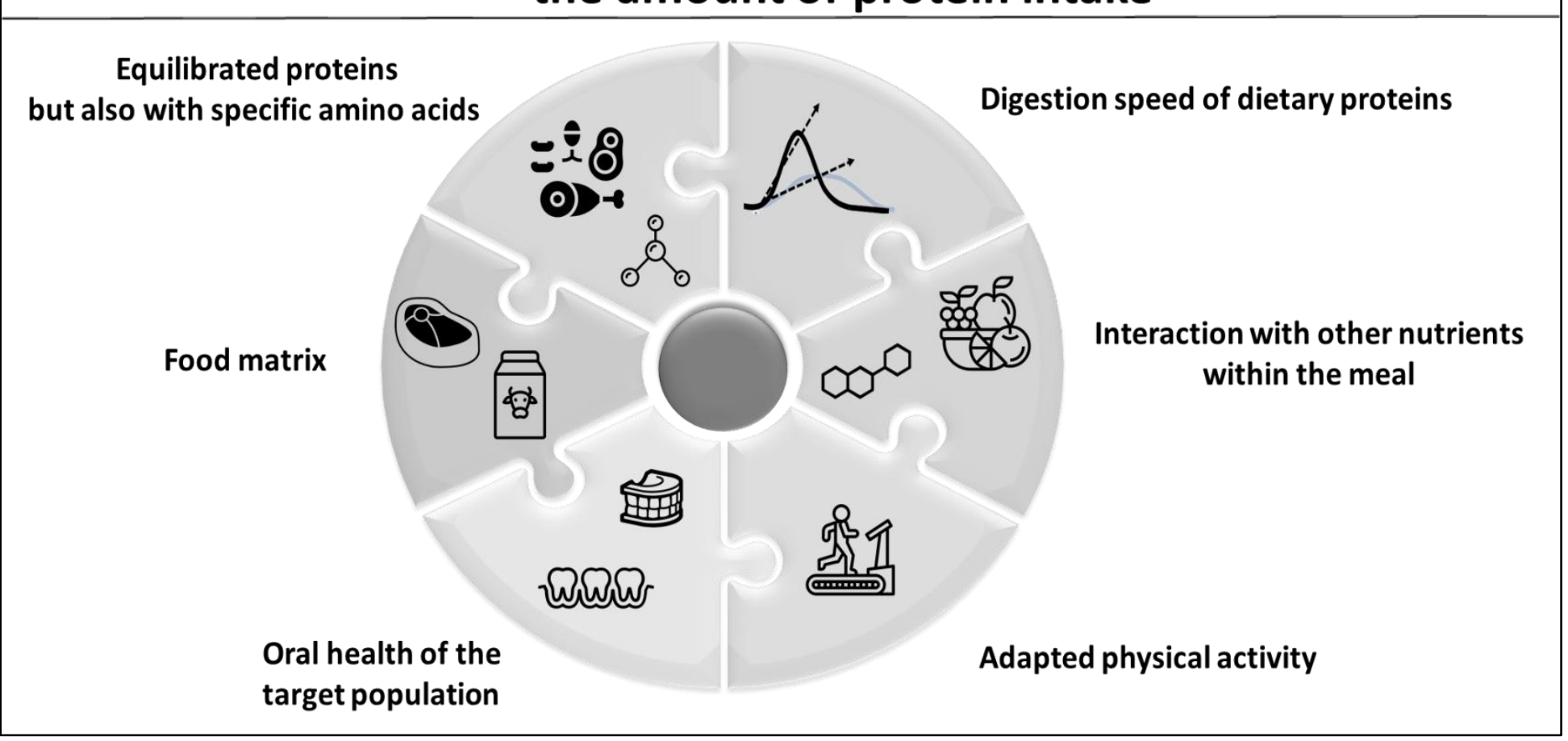

Couple by Gan Khoon, Denture by Jems Mayor; Teeth by Adrien Coquet; Steak by Sandra, Gym by supalerk laipawat, Fruit by Eucalyp, Milk by Tomas Knopp, Molecule by Ben Davis, Protein by Turkkub, Polyphenols by Francesca Ameglio from the Noun Project. 


\section{1- Introduction to Protein Nutrition: The Basics}

The aim of eating dietary protein is to satisfy the body's requirement for amino acids (AA) involved in multiple metabolic pathways. Protein synthesis, however, remains the metabolic pathway that uses the most of the dietary AA to renew body proteins. Because proteins are composed of 20 different AAs, protein nutrition should cover the requirement for all amino acids. Indeed, if the requirement for a single amino acid is not covered, this will have a negative impact on the optimal utilization of all the other amino acids (limiting AAs, see below). Contrary to carbohydrates or lipids, no dedicated amino acid storage takes place in the body, leading to very limited internal availability outside the food intake period. Protein metabolism must adapt constantly by building and breaking down body proteins without challenging the function of organs or tissues. This is emphasized in humans with 9 indispensable AAs which cannot be synthetized de novo and for which the requirement is $100 \%$ dependent on food intake.

\section{Today, the Recommended Daily Allowance (RDA) has been set at $0.83 \mathrm{~g} / \mathrm{kg} /$ day of proteins of "good quality" for healthy young adults. (1)}

However, there is a growing body of evidence that this RDA is too low for the elderly. Indeed, there seems to be a consensus that the need for protein is increased in the elderly not only to maintain muscle mass (2) but also to maintain muscle functionality (3). A recent study of the English cohort 'Newcastle 85+' showed that lower protein intakes $(<1 \mathrm{~g} / \mathrm{kg} / \mathrm{d})$ in people over 85 years of age are associated with higher increases in scores reflecting physical disability and dependence (4). In France, the RDA for proteins has recently been increased from 0.83 to $1 \mathrm{~g} / \mathrm{kg} / \mathrm{d}$ for adults over 65 years of age (5). Apart from quantity, the quality of protein supply is important. A protein of good quality is a protein whose AA composition covers the requirement of each indispensable AA when ingested at the RDA. In Figure 1, protein $A$ is therefore of good quality for the healthy adult population when given at the RDA. By contrast, protein B in Figure 1 does not cover the minimal requirement for lysine, and cannot be considered as a protein of good quality when ingested at the RDA by healthy adults; thus lysine is the limiting AA for optimal body protein synthesis. Protein nutrition follows the barrel/stave theory which has been described extensively in animal nutrition and which is directly applicable to human protein nutrition (6). Briefly, the ingested dietary protein is the barrel composed of staves that represent each amino acid. For a given AA, the height of the stave is the minimum amount at which this amino acid must be present in order to cover its minimum requirement. The stave with the lowest height corresponds to the limiting amino acid and influences the maximal capacity of the barrel, i.e. maximal amino acid retention. With a dietary protein given at the RDA, if the stave of one amino acid becomes shorter then the volume of the barrel will decrease, i.e. amino acid retention will decrease. However, in our example (Figure 1), by doubling the intake of protein $\mathrm{B}$, this dietary protein is then able to fulfill the requirements for lysine. The problem is that to fulfill the minimal requirement of a single AA (Lys), the ingestion of a high amount of protein B will also provide very large amounts of all the other amino acids. Since these "extra" amino acids cannot be stored, they will be wasted and eliminated by oxidation, leading to urea and ammonia production. 


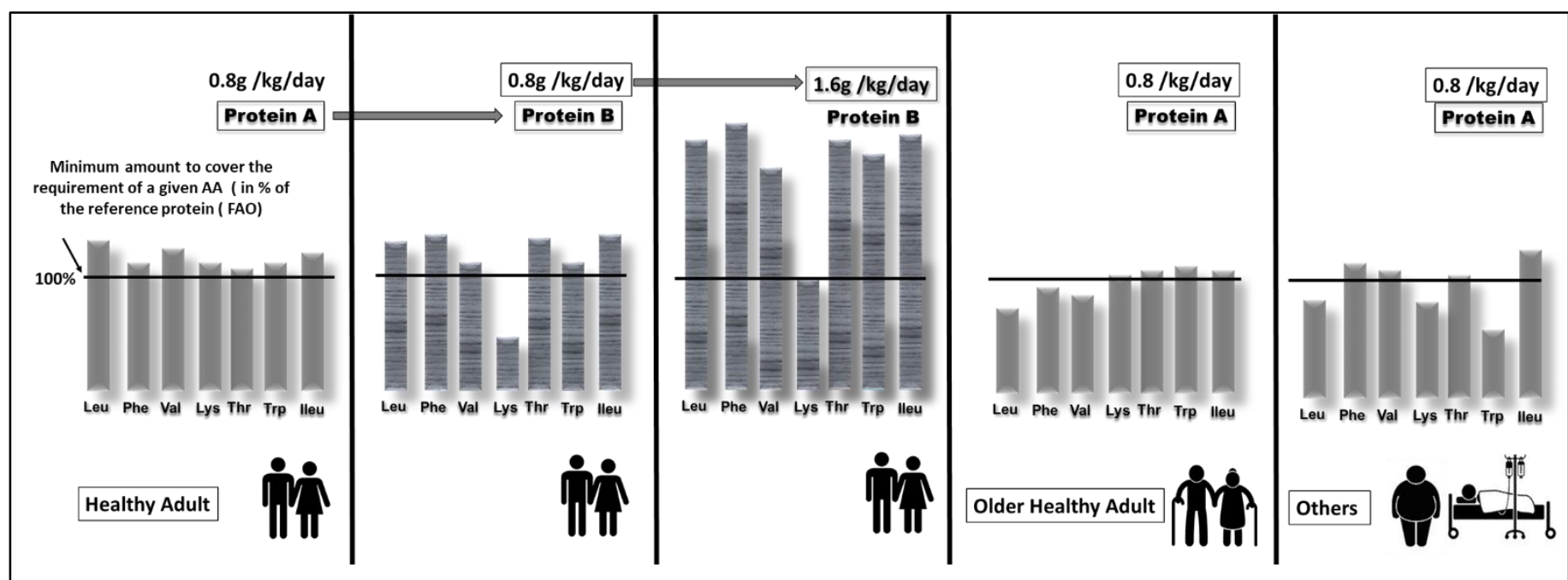

Figure 1

Because the requirements of AA may differ according to different populations, i.e. healthy older adults, obese people, or hospitalized patients, protein A may not be of good quality when given at the RDA because it cannot, for example, fulfill the leucine, phenylalanine or valine requirements in older adults, or the leucine, lysine or tryptophan requirements in another population (see Figure 1). The amount of protein A will also have to be increased in such populations even if this dietary protein is considered to be of good quality in healthy adults.

When a protein is not of good quality according to its amino acid composition, this shortcoming can be palliated by increasing the amount ingested until it covers the minimal requirement of the limiting AA. However, the increase in protein intake and more generally the increase of food intake can be difficult to achieve because: 1) the palatability of proteins is generally not good; 2) increased AA requirements are associated with fragility and physio-pathological conditions, the proteins to be supplied could be too high to be compatible with normal intake in targeted populations; 3) these targeted populations are also characterized by poor appetite and undernutrition; and 4) as AAs in excess of those required cannot be stored, urea production will increase, possibly aggravating weak renal function already present in these populations.

Nutritional strategies targeting protein intake must therefore favor reasonable increases in dietary protein and optimize the composition of what is ingested as much as possible. The present review therefore focuses on the various studies that have formulated a certain number of concepts and also made it possible to identify the various determinants leading to this optimization in the elderly, with, in addition particular attention given to the prevention of sarcopenia.

\section{2- Pulse protein feeding and leucine, "the" anabolic amino acid}

The main function of skeletal muscle is to provide power and strength for locomotion and posture; what is more this tissue is also the major reservoir of body proteins and amino acids. Thus, 
although the loss of muscle proteins has positive effects in the short term by providing amino acids to other tissues, uncontrolled and sustained muscle wasting impairs movement, leading to difficulties in performing daily activities. It also has detrimental metabolic consequences such as reduced ability to mobilize enough amino acids in the case of illness and disease. The resulting weakness increases the incidence of falls and the length of recovery, and when advanced muscle wasting correlates to morbidity and increased mortality (7). Consequently, one of the challenges we have to face is to supply amino acids to those tissues with higher requirements in healthy situations, prevent excessive loss of muscle proteins in catabolic states (8), and ultimately improve muscle recovery.

During the day, protein metabolism is modified by food intake. In adult volunteers, oral feeding is associated with an increase in whole body protein synthesis and a decrease in proteolysis (9-13). Thus, in the case of muscle wasting, muscle protein loss results from an imbalance between protein accretion and breakdown rates that partially stem from a defect in post prandial anabolism. Although each muscle wasting situation is characterized by its specific mechanism(s) and pathways, leading to muscle loss, an increase of catabolic factors such as glucocorticoids, cytokines, oxidative stress, etc., often occurs. It is now well established that these factors have potential deleterious effects on the amino acid and insulin signalling pathways involved in the stimulation of muscle anabolism after food intake (14-18). These signalling alterations lead to the "anabolic resistance" of muscle even if the anabolic factor requirements (amino acids for example) are theoretically covered, i.e. with normal nutrient availability matching the recommended dietary protein allowances in healthy subjects. This anabolic resistance may be partially explained by an increase of the muscle "anabolic threshold" required to promote maximal anabolism and protein retention (19). Since the muscle "anabolic threshold" is higher, the anabolic stimuli (including aminoacidemia) can no longer reach the anabolic threshold and, by consequence, muscle anabolism is reduced with the usual nutrient intake

As mentioned above, the need to increase protein intake to counteract anabolic resistance is not desirable in the elderly with an aging renal function. The answer to the question: How can the intake of AAs be increased during the meal without increasing the daily protein intake? has been found in pulse protein feeding.

The principle of pulse protein feeding is to make sure that the protein intake is above the anabolic threshold in at least one meal during the day. Since total daily protein intake remains low, it leads to lower protein intakes during the other meals of the day, which is a better solution than to spread protein intake over all the meals of the day, since in this case no meal would reach the anabolic threshold. In healthy women, for a total daily protein intake of $1 \mathrm{~g} / \mathrm{kg} / \mathrm{d}$, it was shown that the pulse protein feeding pattern promoted a better nitrogen balance than the spread feeding pattern in older individuals, whereas there was no difference between the pattern in young individuals (20-23). A difference between the two patterns can be obtained only if the total protein intake is at the RDA. If an even protein intake is used in elderly subjects with at least $30 \mathrm{~g}$ of protein per meal, good anabolism will ensue, because the anabolic threshold is attained at each meal. However, it could be considered as a high protein intake $(90 \mathrm{~g} / \mathrm{d})(24)$. 
Pulse protein feeding is particularly useful for feeding elderly undernourished people. Bouillane et al. (25) showed that after 6 weeks, in malnourished or at-risk patients in an inpatient rehabilitation unit, pulse protein feeding resulted in a better increase in lean body mass than an even protein distribution. In this study, in the even protein distribution group, the amount of protein ingested at each meal varied between 12 to $21 \mathrm{~g}$, which was probably never sufficient to stimulate muscle protein synthesis. On the contrary, in the pulse protein feeding group, one meal per day contained on average $48 \mathrm{~g}$ protein, which was above the anabolic threshold, leading to adequate stimulation of muscle protein synthesis. Over the day, it also probably led to a positive influence on muscle protein breakdown, moreover explaining the positive effect on lean body mass.

In the context of global overpopulation with the risk of running out of good quality proteins, pulse protein feeding could also be perceived as a rational and efficient way to meet the protein requirements of healthy elderly subjects.

Despite the recorded effectiveness of pulse protein feeding, lunch remains substantial in quantitative terms to ensure the intake of dietary proteins with real foods and dishes (Figure 2). It also requires significant meal preparation time, cooking and prior organization to vary menus. In addition, as protein palatability decreases with age, there is a significant risk of the elderly not finishing the dishes and therefore not meeting the amino acid requirements over the long term.

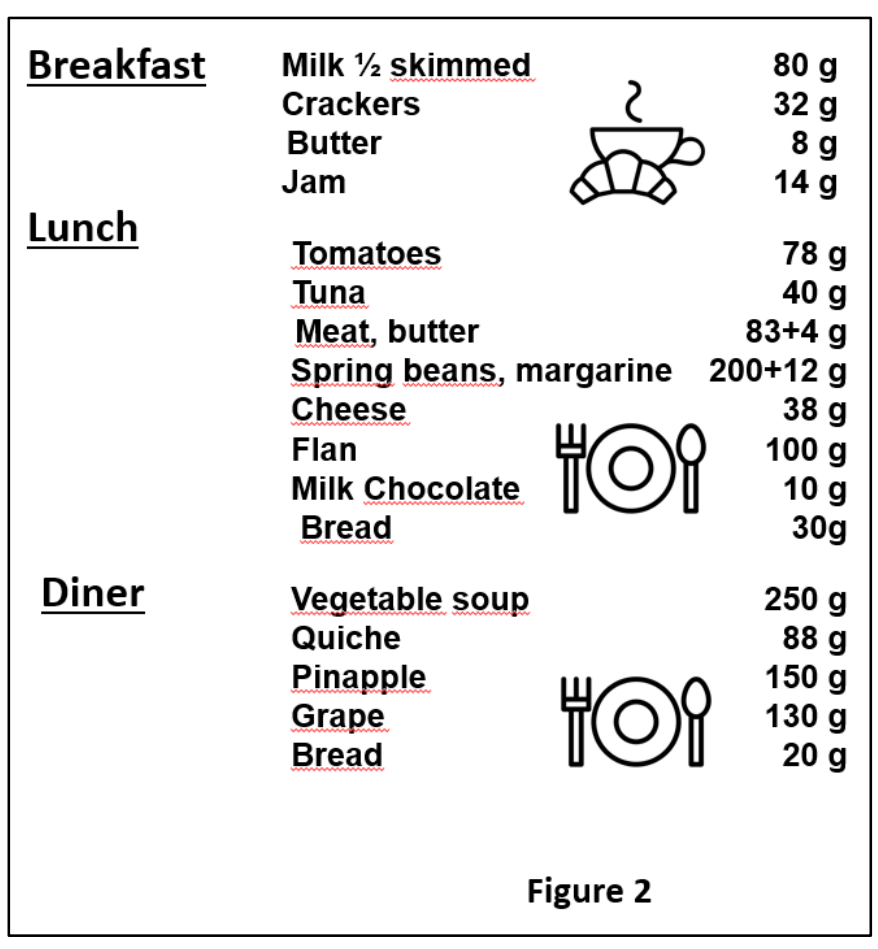

During aging, the loss of muscle sensitivity to the anabolic effect of dietary AA has been linked to an essential amino acid: leucine (26-29). Indeed, leucine is a signal amino acid which is not only a substrate for protein synthesis, it also stimulates an intracellular muscle signaling pathway involved in the initiation of protein synthesis: the mTOR signaling pathway. This suggests that increasing leucine availability may represent a nutritional strategy to overcome the increase in the "anabolic threshold" observed during aging. Studies in both elderly humans and rodents subjected to free leucine supplementation have shown that such supplementations significantly improve muscle protein balance after food intake by increasing muscle protein synthesis and decreasing muscle proteolysis in the post prandial state (30-32). However, the few chronic studies conducted with such free leucine supplementations did not succeed in promoting the prevention of sarcopenia $(33,34)$. Choosing free leucine as a supplement over a normal protein diet triggers de-synchronization between the leucine signal and the increase of all amino acids (19). Indeed, free leucine is absorbed immediately whereas the other amino acids are released later after gastric emptying and proteolytic 
digestion in the gut. This "non-synchronization" between the stimulation of muscle leucineassociated protein metabolism pathways and the delayed availability of amino acids as substrates may be the reason why protein anabolism is stimulated for only a very short time during the post prandial period and thus could not result in significant muscle protein accretion. Studies on synchronized leucine signals and amino acid availability have been performed using leucine rich proteins that are rapidly digested (whey proteins)(35). With such proteins, leucine availability is increased simultaneously with that of the other amino acids to reach the increased muscle anabolic threshold. However, as observed for free leucine supplementation, when such dietary proteins were given, muscle anabolism was improved considerably (36). However, in the long term in elderly rodents, muscle mass remained unchanged (37). Positive results could only be recorded if whey proteins were given in the form of a chronic high protein diet (twice the RDA) (38). However, Magne et al. $(39,40)$ showed that in elderly rodents recovering from acute muscle atrophy, leucine rich proteins were nevertheless efficient in improving the recovery of muscle mass whereas free leucine supplementation remained ineffective.

During aging, protein requirement is increased, partly explained by anabolic resistance to amino acids and in particular to leucine. Dietary protein intake must be increased but vigilance is required regarding the potential deleterious effects of high protein diets in this population and the difficulty of supplying more AA. The pulse feeding diet has shown positive results but its implementation remains complex and may require oral nutritional supplements that are not widely accepted by this population (41). Free leucine supplements do not seem to show a positive effect due to the desynchronization of the arrival of amino acids in the peripheral blood. Leucine-rich and quickly digested proteins like whey proteins enhance the anabolic effect of food intake but remain non-optimal in the elderly for the preservation of muscle mass if given at the RDA.

\section{3- Energy substrates for enhancing the anabolic potential of dietary proteins in the elderly}

Back in the 1980s, Waterlow et al. and Reeds et al. $(42,43)$ calculated the daily energy cost of protein turnover as approximately $18 \mathrm{~kJ}(4.3 \mathrm{kcal}) / \mathrm{kg}$ body weight, or about 20 percent of the basal metabolic rate, showing that protein metabolism is an energy-requiring process. The first conclusion is therefore that in order for the anabolic effects of dietary proteins to have an optimal effect, they must be combined with energetic substrates, even more so in the elderly for whom this effect is precisely non-optimal. In this review we discuss the effect of the nature and the timing of this energy supply on the mechanisms regulating muscle mass during aging. However, we also point out the potential sarcopenic effect of the ingestion of simple sugars. 
a) Could sugars be sarcopenic?

The first answer to this question that comes to mind is "of course not". In the context of a normal and balanced diet, the nature of the energy consumed has only marginal effects on the regulation of muscle protein metabolism. In the short term, for one meal, co-ingestion of sugar with proteins should lead to higher insulin secretion. This anabolic hormone increases muscle anabolism essentially through reduced muscle proteolysis. However, in the long term, and considering that more and more people do not eat a normal and balanced diet, the answer to this question is different.

Indeed, since the 1950s, added sugar consumption (=sugars that are not naturally present in our diet like in fruits but that are added artificially) has been steadily increasing, leading to highfructose intake, either in the form of sucrose (sucrose is half glucose, half fructose) or directly as pure fructose, in particular since the introduction of high-fructose corn syrups. This consumption is chronic, daily, and continues for months and years. Such a diet (HCIAS= high chronic intake of added sugar) is thought to trigger many metabolic disorders. High fructose intake induces an increase in liver lipid content, leading to insulin resistance and then to dyslipidemia, hypertension, oxidative stress, inflammation and non-alcoholic fatty liver disease. As already explained, inflammation, oxidative stress, and insulin resistance, which are also hallmarks of aging, are probably responsible for the increase in the muscle anabolic threshold observed during aging. HCIAS could therefore accelerate the rate of ageing, and indeed be sarcopenic (44).

Indeed, it was shown that after 5 months of a high sucrose diet in old rats, sucrose fed rats lost significantly more lean body mass than starch fed rats $(-8.1 \%$ vs $-5.4 \%$ respectively) and final muscle mass was $11 \%$ higher in starch than in sucrose fed rats (45). Accordingly, meal-induced stimulation of muscle protein synthesis was significantly lower in sucrose $(+7.3 \%)$ than in starch fed rats $(+22 \%)$. This result was in line with an insulin sensitivity index divided by $2(45)$.

More generally, liver damage, as induced by fructose, was shown to impact muscle, not only through insulin resistance, inflammation and oxidative stress, but also through endoplasmic reticulum stress, a decrease in the peripheral availability of anabolic factors such as hormones and amino acids, and through the production of catabolic effectors such as various hepatokines, methylglyoxal, and uric acid (46). In agreement with these results, a prospective study showed that the consumption of added sugars in the diet of older people was associated with frailty (47). Thus, given all these elements, it seems likely that sugars, or more precisely HCIAS, are sarcopenic (44).

b) De-synchronized energy boluses during the post prandial period

As developed above (paragraph 2), when given in the long-term, whey proteins alone do not appear to be an optimal nutritional strategy to prevent or slow down muscle wasting during aging 
or catabolic states (48-51). This could be explained by the nature and intensity of the catabolic state and by the fact that the digestion of whey proteins may be too rapid during a catabolic situation to sustain the anabolic postprandial amino acid requirement necessary to elicit an optimal anabolic response (52). Indeed, the stimulation of muscle protein synthesis has a defined and limited duration during the postprandial period $(53,54)$. Atherton et al. showed that whey ingestion is only able to stimulate muscle protein synthesis for $2 \mathrm{~h}$ and has been named " the muscle full effect" (53). The leucine content of a complete meal drives peak activation but not the duration of skeletal muscle protein synthesis (55). Interestingly, it has been shown recently that the duration of the postprandial stimulation of muscle protein synthesis in healthy conditions can nevertheless be prolonged by maintaining the cellular energy status with the supplementary ingestion of a desynchronized carbohydrate load after food intake $( \pm 150 \mathrm{~min})(56)$. Such a prolongation could be a complementary strategy to improve the whey protein supplement effect during aging, or in other catabolic situations in which these proteins are still not optimal. This hypothesis has been tested in preclinical models of aging (rodents) and catabolic states (mini pigs) in which rapid sugars like glucose and sucrose were given to sustain energy supply to skeletal muscle 90-120 min after the beginning of food intake. Unfortunately, this desynchronized energetic bolus during the post prandial period has shown no beneficial effect on the intensity or the duration of anabolism initiated by whey proteins in either model (57).

c) Energy boluses during the post-absorptive state to attenuate muscle loss during the night

The overnight sleep period represents the longest period during the day with no AA intake and as a consequence, results in both reduced rates of muscle protein synthesis and increased rates of muscle protein breakdown (58). It can be hypothesized that the additional muscle protein gain initiated by the ingestion of whey protein intake at lunch may then be lost at night, explaining the disappointing results of whey protein supplementation to reduce and slow down sarcopenia in the long term. Thus, attenuating the overnight losses of lean tissue mass (including muscle) would potentially be beneficial in helping to maintain lean tissue/muscle mass in the elderly by sparing the anabolic effect of whey protein ingested at lunch.

Several strategies have been explored to take advantage of this nutritional window, including presleep protein ingestion, combined or not with exercise. The impact of such interventions on muscle, lean mass and protein synthesis are variable, although some evidence suggests a beneficial effect, as has been reviewed elsewhere $(59,60)$. While these strategies aim at improving overnight protein synthesis (normally low (61)), another possibility would consist in tackling the protein breakdown that takes place concomitantly during the food deprivation period. Indeed, early studies on food-deprived animals have shown that fructose feeding induced a reduction in hepatic AA catabolism (62), resulting, as with other carbohydrates $(63,64)$, in a protein sparing effect. This interaction between carbohydrates and AA metabolism in the post-absorptive state has been known since the first studies of Cuthbertson and Munro (65) and Gamble (66) on humans and on both young and older adults $(67,68)$ in particular regarding physiological conditions, such as in catabolic states in which energy intake is limited $(69,70)$. In addition, carbohydrates have also 
been shown to exert a better nitrogen-sparing effect than fat, particularly under circumstances of limited energy supply (71).

Associated with the consumption of soft drinks and pastries rich in high-fructose corn syrup, rates of obesity and other metabolic dysregulations are increasing and have been suggested by some authors to be linked to fructose intake (72). However, during the night with only limited to no energy supply, it is clear that fructose is converted mostly into glucose and glycogen, and no deleterious effects on insulin sensitivity or lipid homeostasis have been observed so far. In this context, the specific positive effects of fructose could be expected to occur through its interaction with AA metabolism. We observed (73) that, although both fructose and glucose spared body

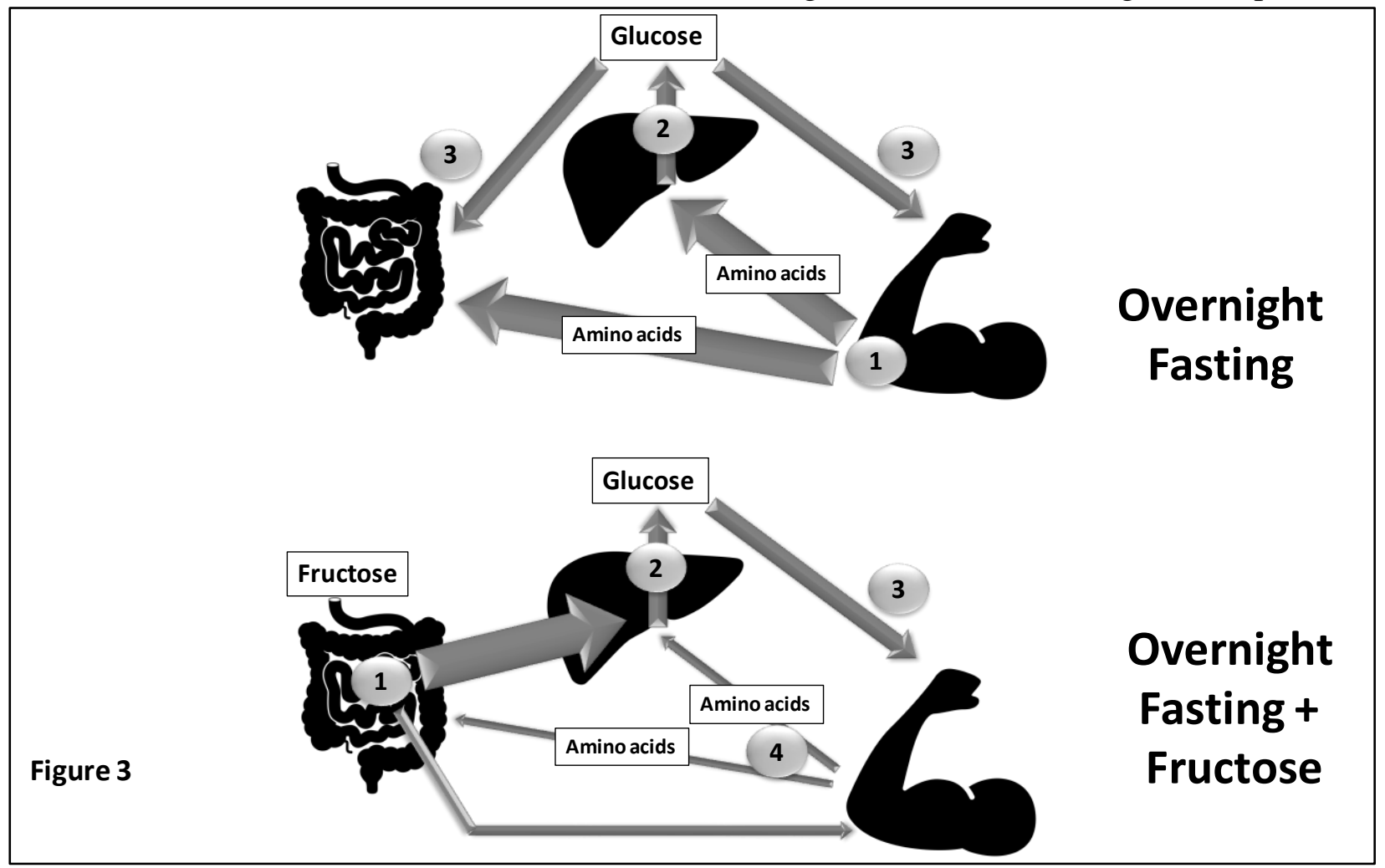

weight and lean mass, fructose feeding was more efficient than glucose in sparing liver, skeletal muscle, and intestinal masses. Fructose also significantly spared fat mass, which may be of specific interest in muscle wasting conditions: 1) because conserved fat mass reduces the risk of morbidity and mortality in hospitalized patients, particularly in elderly people (74, 75); and 2) because during protein-energy restriction larger fat stores can delay AA utilization. Overall, this study reported an inter-organ metabolic strategy resulting in reduced hepatic amino acid utilization for neoglucogenesis able to preserve the mass of major tissues, and more generally the lean mass of the body (Figure 3). We also showed (73), indirectly, that some tissues such as skeletal muscle remained metabolically stable and benefited from deep modifications in other organs, such as the liver, to improve their carbohydrate storage and maintain their masses. The fact that fructose feeding preserved both lean and fat mass without inducing hyperlactatemia and while maintaining low uric acid and triglycerides suggests that this nutritional intervention, in addition to protein supplements given at lunch, may be of potential use in the elderly in the form of a pre-sleep longlasting carbohydrate release bolus. 
Simple sugar can be sarcopenic if ingested in excessive amounts on a daily basis.

Targeted energetic boluses given 90 min after food intake may not be efficient to sustain post prandial muscle protein synthesis initiated by whey proteins.

Energetic boluses given apart from dinner $(\geq 2 \mathrm{~h})$, during the night with no other nutrient intake, could limit post-absorptive muscle breakdown and thus preserve the anabolic effect of whey protein supplementation. Fructose could be favored in this specific strategy as it is more efficiently transformed into glucose/glycogen and is able to spare more fat mass than glucose.

\section{4- Oral health and its impact on amino acid availability}

The digestive process starts in the mouth and food bolus characteristics (that will be further degraded in the rest of the gut) are highly dependent on masticatory function $(76,77)$. The purpose of mastication is to prepare the food bolus via the mechanical disruption of the morsel of food into small particles and moisturizing by saliva foods that the can swallowed. Some chemical digestive processes also start in the mouth due to the activation of alpha-amylases and lipases. During normal aging, several determinants of oral function can be progressively impaired such as decreased tongue thickness, the cross sectional area of the masseter, mixing ability, and tongue movement (78). However, masticatory function can be maintained through minor adaptations like an increase in the number of masticatory cycles to offset reduced masticatory forces, and generate a safe, swallowable bolus (79). On the contrary, when the dental state is impaired (decreased number of teeth, decreased occlusal force) and when the quantity and quality of the saliva are lower, masticatory function can be impacted negatively. This leads to the insufficient breakdown of the bolus and a higher proportion of large particles (80). This masticatory function remains impaired in edentulous individuals even when wearing a denture (81).

This alteration of oral health and masticatory function is particularly present in sarcopenic, prefrail and frail populations. Indeed, several studies (observational and longitudinal) have demonstrated that a frail group of elderly adults present relatively fewer (functional) teeth, lower occlusal force/ masseter thickness and overall impaired masticatory function along with a lower muscle mass index and nutritional state compared to a robust elderly group $(82,83)$. Consistent with the above, alterations in dental status, chewing and swallowing are considered to be among the determinants of malnutrition in elderly adults (84). This raises the question whether impaired masticatory function is a cause or a consequence (or both) of the overall muscle mass loss and nutritional state observed in frailty. It has been repeatedly demonstrated that tooth loss or edentulism is associated with diet selection (fewer vegetables and fruits, leading to a lower intake of certain vitamins and dietary fibers) and overall decreased energy and protein intake (85-87). This diet selection is partially driven by the incapacity of edentulous elderly people to generate a swallowable food bolus (see above)(88). This alone, via a lower energy and protein intake, could participate in worsening sarcopenia and frailty directly through a decrease in dietary protein supply. However, food choice is not the only parameter that can reduce amino acid availability in elderly people. Indeed, since edentulous and denture wearing elderly people chew less, a reduction in the availability of nutrients (including amino acids) can occur due to insufficient mechanical disruption of proteins in the mouth. To test this hypothesis, we carried out a clinical study on 
elderly volunteers in which amino acid bioavailability from beef meat was assessed in fully dented individuals compared to edentulous ones wearing complete dentures (89). We showed that denture wearers presented delayed absorption of proteins associated with an overall lower AA occurrence in the blood during the post-meal period. It was also associated with a lower anabolism at the whole body level (Figure 4) (89). This means that, in a situation of similar dietary protein intake, reduced amino acid bioavailability due to impaired mastication functionality resulted in non-optimal protein nutrition to sustain the AA requirement.

The last question that remains is the following: can the altered amino acid availability observed in elderly people presenting altered masticatory functions be reversed? Few studies have tackled this issue but they tend to show that this area of research remains to be investigated in the field. One potential lever to optimize AA availability is the use of foods textured to fit elderly oral capabilities to overcome impaired masticatory function. Another path is to assess the impact of the food matrix itself or in association with masticatory impairments (90) (see paragraph 5). This was tested by Pennings et al (91) on elderly men wearing dentures offered minced or non-minced meat in a crossover experimental design. In the denture wearing volunteers presenting impaired masticatory function (81), beef proteins were more rapidly digested and AA availability improved after eating minced meat. Pre-processing of foods targeted at elderly edentulous/ denture wearing populations is therefore an area of research that requires further investigation. Another way to improve both protein intake and digestibility is to enhance masticatory function via training. This has been investigated by Kikutani et al (92) who showed increased body weight and plasma albumin in frail elderly Japanese volunteers after both oral functional training and protein/energy supplementation compared to supplementation alone. Again, such beneficial effects of oral

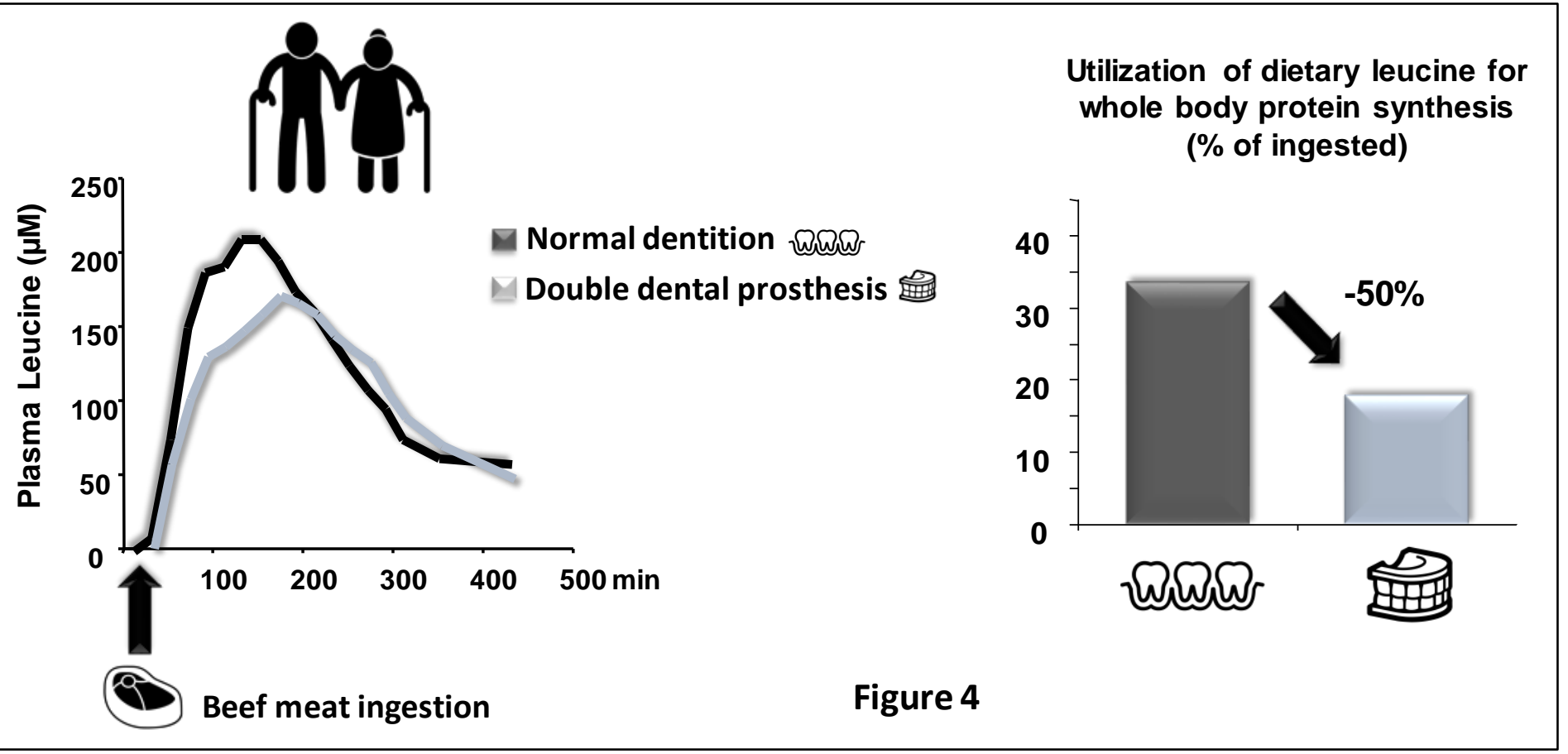

training interventions require further investigation, with a detailed assessment of the nutritional state of elderly volunteers. 
Oral health is certainly an important concern during aging that can directly affect food choice linked to texture, mastication, food bolus formation and swallowing. Aging itself has a slight impact and some adjustment of mastication can compensate for a decrease in masticatory force or tongue motility, for example.

The challenge of maintaining correct food intake and optimal absorption in the elderly presenting severe oral deficiencies is to develop/design food textures that match both their oral sensory-motor capabilities and their nutritional needs.

\section{5- The food matrix as a strong determinant of amino acid availability and dietary protein anabolism potential in the elderly}

For a protein source to be of good nutritional value and content quality, the indispensable amino acids contained in it must be well balanced with respect to body requirements. They must also be bioavailable, meaning that the proteins have to be highly digestible to ensure the optimal release of amino acids in the bloodstream. The digestibility of food proteins depends on the intrinsic structure of the proteins and on their physical and chemical environment, the so-called 'matrix effect'.

The effect of protein structure on digestibility is illustrated by the very low intestinal digestibility of zein (corn protein), a very compact protein of low solubility, when compared to whey proteins (30\% vs 90\%) (93). Despite its leucine content, i.e. 15\% (94) which is interesting for the elderly (see Paragraph 2), its usefulness as a protein source for older adults is nevertheless lessened by its low digestibility. Indeed, it would be necessary to double its intake if used as a single source of dietary proteins. In addition, the molecules associated with dietary proteins within the matrix or the meal can also limit the efficiency of protein digestion. This is particularly the case for compounds that block the proteolytic activity of digestive enzymes (trypsin inhibitors, polyphenols, etc.). Cooking generally leads to the inactivation of trypsin inhibitors. It improved the intestinal digestibility of a soy protein concentrate that was considerably improved by autoclave treatment (95). It has also been shown that the fermentation of seeds before cooking significantly reduces the activity of these enzymes. Regarding polyphenols, we observed that the digestion of meat proteins was not impacted by the presence of polyphenol-rich fruits and vegetables in the meal, whereas the intake of the same polyphenols in equivalent quantities, in the form of extracts, significantly decreased the apparent digestibility of proteins (96). It is known that, by complexing with dietary proteins or digestion enzymes, polyphenols can reduce the efficiency of digestion. However, it is interesting to note that the effect of these bioactive plants can be very different depending on whether they are in free form, as an extract (in food supplements, or as a food preparation additive), or in their original matrix. This could partly explain the lack of effect of supplementation with polyphenols in free form, as natural antioxidants, on muscle mass preservation during aging $(97,98)$. This is because the beneficial antioxidant effect is counter-balanced by a decrease in protein digestion and in amino acid bioavailability. 
In addition to digestibility as such, digestion speed, which is the incremental increase of AAs over time, can be very different between dietary proteins and lead to very different hyperaminoacidemia levels when they are ingested at the same amount. (Figure 5) In older adults, it has been shown that the dietary proteins with fast digestion speeds and which generate the highest

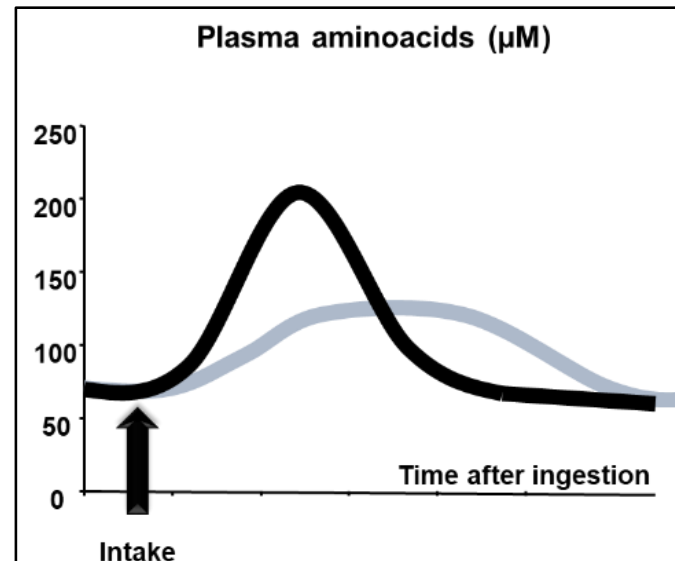

Fast digested protein
Digestion speed ( $\mu$ moles per min)

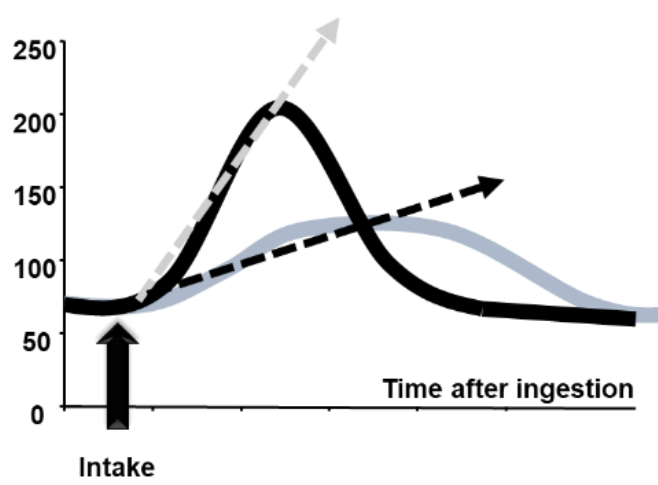

Slow digested protein
Maximal plasma amino acids level $(\mu \mathrm{M})$

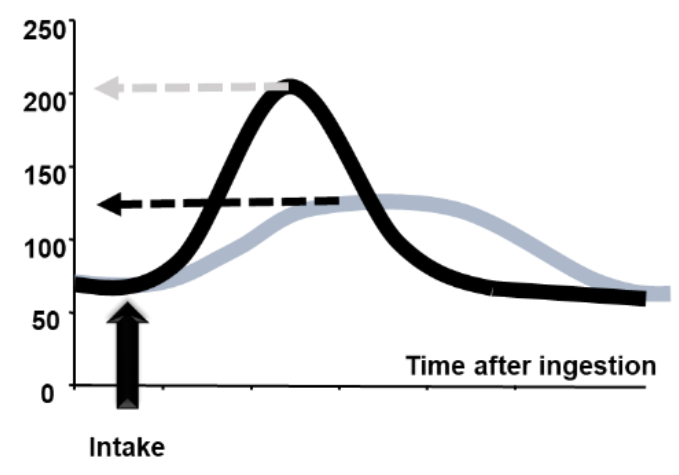

Figure 5

amino acidemia were much more efficient in initiating muscle anabolism (see paragraph 2). A case study was performed to compare two milk proteins with similar digestibility, i.e. casein and whey proteins (99). Whey proteins are rapidly digested whereas caseins, which coagulate in the stomach, are the best example of slowly digested animal proteins. In older adults, whey proteins are much more efficient than casein in promoting muscle anabolism when ingested at $30 \mathrm{~g} / \mathrm{meal}$. Ranking proteins according to their speed of digestion remains a challenge. Indeed, beyond the specific properties of each protein, the technological processes used to prepare foods, such as cooking, can alter digestion kinetics. With meat matrices, we have shown that the digestion speed of proteins increases by heating up to a temperature of $70-75^{\circ} \mathrm{C}$, above which it declines(100). Heat treatment leads to the denaturation of the protein, which results in the externalization of the hydrophobic amino acids that become accessible to digestive proteases. At temperatures above $70^{\circ} \mathrm{C}$, aggregation and spherical congestion are initiated by oxidation reactions, hydrophobic interactions or covalent binding, which reduce accessibility to proteases and thus decrease the speed of meat protein digestion $(100,101)$. Although cooking temperature has little effect on the total bioavailability of amino acids in meat (digestibility), which in all cases remained very high $(100,102)$, we observed that by increasing the digestion speed, it can have a very significant positive effect on the bioavailability and assimilation of meat amino acids in the elderly (103).

The second example is milk processing. We indeed observed that gelling milk (with rennet or gluconodeltalactone) delays the duodenal occurrence of proteins and therefore decreases the digestion speed of dietary protein, leading to a modification of the absorption of dietary amino acids (104, 105). Several hypotheses could explain this result: very long gastric retention (associated with considerable digestive secretions), and increased resistance to digestive proteolysis. It is also interesting to note that between milk and yoghurt, ileal digestibility is not modified (106). As with heat treatments of meat, gelation affects protein digestion speed but not the quantity digested. 
The characteristics of the food matrix significantly influence the digestion speed of dietary proteins and the bioavailability of amino acids, and modulate protein assimilation efficiency in the elderly.

Technological processing, by acting on the food matrix, helps in optimizing digestive parameters according to the specific characteristics of the elderly.

Thus, for the elderly, in whom protein requirements tend to increase while their spontaneous intake decreases, optimized food matrices could decrease the risk of inadequate intakes of indispensable amino acids, and improve assimilation efficiency.

\section{6- Could the optimization of protein nutrition include plant proteins in the elderly?}

Due to the negative environmental impact of intensive animal production, and because of the benefits to health of consuming fruit, vegetables, and grains, dietary guidelines in several countries tend to advise increasing plant protein intake with a corresponding increase of the plant/animal protein ratio in human nutrition $(107,108)$. In addition, consumers appear to agree with this transition to more plant proteins due to ethical considerations with regard to animal welfare and because of nutritional messages that accuse red meats as being harmful to health if consumed in large amounts $(109,110)$.

The search for alternative protein sources and transitioning towards more sustainable, plant-based nutrition has received much attention in the past decade (111). Indeed, although new protein sources such as algae, micro-algae and insects are currently attracting growing interest, the most relevant option in the - urgent - short term is to take better advantage of the huge amount of plant proteins already available. However, besides certain technical and organoleptic issues, one of the main obstacles to using plant proteins in human nutrition is generally the low nutritive value classically attributed to them, because of their unbalanced composition in indispensable amino acids (IAA), and because they are generally less digestible than animal proteins (112). Solutions to optimize indispensable amino acid supply with plant foods include: combining plant foods with complementary amino acid compositions, amino-acid complementation, consuming higher amounts of plant-based products on a more frequent basis, and enhancing the nutritional quality of crops through genetic engineering (113).

During aging, the impact of lower quality plant proteins was exemplified in older healthy volunteers by Gorissen et al. (114). When given at 35g per meal, casein is unable to stimulate muscle protein synthesis, illustrating anabolic resistance to normal protein intake during aging. Whey proteins, speedily digested and rich in leucine, were able to stimulate anabolism when given at the same amount whereas, like casein, wheat protein remained inefficient. The absence of efficiency is explained by the lower content of lysine in cereal protein sources (about 50\%), so this AA was limiting (see paragraph 1). Although when wheat proteins were almost doubled (60g), an anabolic effect was again recorded in skeletal muscle. This study clearly showed that if a plant protein with an unbalanced AA composition is consumed, the quantities that must be ingested to stimulate protein anabolism would be of a magnitude impossible to maintain in the elderly in the long term. It is noteworthy that this is also true in younger individuals but it is aggravated during 
aging due to anabolic resistance. It is known that plant proteins have to be mixed, for instance cereals with leguminous seeds, in order to re-equilibrate the indispensable amino acid composition when ingested. This strategy, if followed correctly, has been shown to be safe enough to cover the requirement of the essential AAs and is therefore optimal for anabolism in the healthy young adult population (110). However, is this strategy sufficiently safe to be applied directly to the elderly for whom an increased need for AA has been demonstrated, even in individuals considered to be in good health? This was tested in a pre-clinical study by Berrazaga et al. (115). They showed that if wheat proteins were mixed with either faba bean, lentil or pea proteins, the resulting diet remained inefficient in stimulating muscle protein synthesis in old rats by contrast to whey proteins consumed at the same amount. This clearly shows that a significant increase in protein intake must be considered for the elderly when consuming a diet whose protein sources are solely of plant origin, and even if they are AA-balanced for younger adult individuals. This finding was supported by the observation of Jarzaguet et al., who tested a plant protein, i.e. soy protein which, despite being well balanced in essential amino acids, remained ineffective in stimulating anabolism in old rats if given at a level that was efficient in younger adults (116). This difference in anabolic effect can be explained by the lower content of indispensable amino acids, especially leucine, in plant proteins vs animal proteins (117).

This implies that protein intake with only plant proteins must be higher than with animal proteins, which would be undoubtedly tricky to achieve in an elderly population. However, to significantly "green" dietary proteins intended for the elderly, a portion of high quality animal protein should remain in the diet in order to keep the total protein intake at values compatible with the food intake of these individuals. Recently, it has been shown that a blend of $70 \% 130 \%$ of balanced AA plant proteins /whey proteins can be as efficient as whey alone at stimulating muscle anabolism in old rats if the total protein intake per meal is increased by only $25 \%$ (116).

In conclusion, although nearly all epidemiological studies converge regarding the protective effect of meat (animal) consumption on sarcopenia (118), the health benefits of plant-proteins have yet to be investigated extensively (119) and more studies are needed to evaluate the effectiveness of plant proteins in the prevention of muscle mass and strength loss.

Plant proteins are generally of lower nutritional quality than animal proteins, but this does not hinder "greening" the dietary proteins of the elderly if simple rules are followed:

Vegetal protein sources should be mixed to avoid unbalanced protein AA consumption.

A portion of high quality animal proteins in the diet should be maintained.

The daily intake of total proteins should be increased. Above $50 \%$ of vegetable proteins in the diet, the risk of inadequate protein intake is first linked to the quantity of proteins consumed, then above $70 \%$ the nature of the proteins consumed becomes significant, and the percentage of legumes, nuts and seeds consumed must be increased to prevent lysine deficiency in particular (120) 
More studies are also needed to evaluate the effectiveness of plant proteins in the prevention of muscle mass and strength loss

\section{7- General Conclusion}

Aging is associated with multiples deficiencies, which challenge the efficiency of protein nutrition even when the RDA for dietary proteins is respected. These alterations which are both metabolic (anabolic resistance) or functional (oral health) will have an impact that will be more or less important depending on the age but also the physiopathological state of the person. In this review we have highlighted several potential determinants that may be taken into account or on which, attention should be paid, depending on the clinical and health examination of the person (see grapical abstract). As a result, the strategy put in place to optimize the efficiency of the protein supply must be multimodal because a single lever cannot be sufficient but also because some of them cannot be implemented depending on the state senior's health. The equation is indeed complex to solve, but taking into account the individual and personalized limitations of each person still allows the implementation of the solutions that we have mentioned in this review

\section{8-Acknowledgments}

None besides the authors.

\section{9- Conflict of interest}

None

\section{0- Financial support}

Not applicable

\section{1- References}

1. EFSA Panel on Dietetic Products NaAN. Scientific Opinion on Dietary Reference Values for protein. EFSA Journal. 2012;10(2):2557.

2. Traylor DA, Gorissen SHM, Phillips SM. Perspective: Protein Requirements and Optimal Intakes in Aging: Are We Ready to Recommend More Than the Recommended Daily Allowance? Advances in nutrition. 2018;9(3):171-82.

3. Coelho-Junior HJ, Milano-Teixeira L, Rodrigues B, Bacurau R, Marzetti E, Uchida M. Relative Protein Intake and Physical Function in Older Adults: A Systematic Review and MetaAnalysis of Observational Studies. Nutrients. 2018;10(9).

4. Mendonca N, Granic A, Mathers JC, Hill TR, Siervo M, Adamson AJ, et al. Prevalence and determinants of low protein intake in very old adults: insights from the Newcastle 85+ Study. European journal of nutrition. 2018;57(8):2713-22.

5. Experts PA. Protein intake: dietary intake, quality, requirements and recommendations. ANSES reports 2007; https://www.anses.fr/fr/system/files/NUT-Sy-ProteinesEN.pdf. 
6. Mitchell HH, Block RJ. Some relationships between the amino acid contents of proteins and their nutritive values for the rat. The Journal of biological chemistry. 1946;163:599-620.

7. Cruz-Jentoft AJ, Bahat G, Bauer J, Boirie Y, Bruyère O, Cederholm T, et al. Sarcopenia: revised European consensus on definition and diagnosis. Age Ageing. 2019;48(1):16-31.

8. Obled C, Papet I, Breuillé D. Metabolic bases of amino acid requirements in acute diseases. Curr Opin Clin Nutr Metab Care. 2002;5(2):189-97.

9. Rennie MJ ER, Halliday D, Matthews DE, Wolman SL \& Millward DJ. Muscle protein synthesis measured by stable isotope techniques in man: the effects of feeding and fasting.

Clinical Sciences. 1982;63:519-23.

10. Pacy PJ PG, Halliday D, Quevedo MR, Millward DJ. Nitrogen homeostasis in man: the diurnal responses of protein synthesis and degradation and amino acid oxidation to diets with increasing protein intakes. Clin Sci (Lond) 1994 Jan;86(1):103-16. 1994;86(1):103-16.

11. Boirie Y, Gachon P, Corny S, Fauquant J, Maubois JL, Beaufrere B. Acute postprandial changes in leucine metabolism as assessed with an intrinsically labeled milk protein. Am J Physiol 1996 Dec;271(6 Pt 1):E1083-91. 1996;271(6):E1083-E91.

12. Volpi E, Lucidi P, Cruciani G, Monacchia F, Reboldi G, Brunetti P, Bolli GB, De Feo P. Contribution of amino acids and insulin to protein anabolism during meal absorption. Diabetes 1996 Sep;45(9):1245-52. 1996;45(9):1245-52.

13. Prod'homme M, Rieu I, Balage M, Dardevet D, Grizard J. Insulin and amino acids both strongly participate to the regulation of protein metabolism. Current Opinion in Clinical Nutrition and Metabolic Care. 2004;7(1):71-7.

14. Balage M, Averous J, Remond D, Bos C, Pujos-Guillot E, Papet I, et al. Presence of lowgrade inflammation impaired postprandial stimulation of muscle protein synthesis in old rats. Journal of Nutritional Biochemistry. 2010;21(4):325-31.

15. Rieu I, Sornet C, Grizard J, Dardevet D. Glucocorticoid excess induces a prolonged leucine resistance on muscle protein synthesis in old rats. Experimental Gerontology. 2004;39(9):1315-21.

16. Rieu I, Magne H, Savary-Auzeloux I, Averous J, Bos C, Peyron MA, et al. Reduction of low grade inflammation restores blunting of postprandial muscle anabolism and limits sarcopenia in old rats. The Journal of Physiology. 2009;587(22):5483-92.

17. Lang $\mathrm{CH}$, Frost RA. Glucocorticoids and TNFalpha interact cooperatively to mediate sepsis-induced leucine resistance in skeletal muscle. Molecular medicine (Cambridge, Mass). 2006;12(11-12):291-9.

18. Marzani B, Balage M, Vénien A, Astruc T, Papet I, Dardevet D, et al. Antioxidant supplementation restores defective leucine stimulation of protein synthesis in skeletal muscle from old rats. Journal of Nutrition. 2008;138(11):2205-11.

19. Dardevet D, Remond D, Peyron M-A, Papet I, Auzeloux I, Mosoni L. Muscle Wasting and Resistance of Muscle Anabolism: The "Anabolic Threshold Concept" for Adapted Nutritional Strategies during Sarcopenia. Scientific World Journal. 2012:1-6.

20. Arnal MA, Mosoni L, Boirie Y, Houlier ML, Morin L, Verdier E, et al. Protein feeding pattern does not affect protein retention in young women. Journal of Nutrition. 2000;130(7):1700-4.

21. Arnal MA, Mosoni L, Dardevet D, Ribeyre MC, Bayle G, Prugnaud J, et al. Pulse protein feeding pattern restores stimulation of muscle protein synthesis during the feeding period in old rats. Journal of Nutrition. 2002;132(5):1002-8. 
22. Arnal MA, Mosoni L, Boirie Y, Gachon P, Genest M, Bayle G, et al. Protein turnover modifications induced by the protein feeding pattern still persist after the end of the diets. American Journal of Physiology - Endocrinology and Metabolism. 2000;278(5):E902-E9. 23. Arnal MA, Mosoni L, Boirie Y, Houlier ML, Morin L, Verdier E, et al. Protein pulse feeding improves protein retention in elderly women. Am J Clin Nutr. 1999;69(6):1202-8. 24. Moore DR, Churchward-Venne TA, Witard O, Breen L, Burd NA, Tipton KD. Protein ingestion to stimulate myofibrillar protein synthesis requires greater relative protein intakes in healthy older versus younger men. J Gerontol A Biol Sci Med Sci. 2015;70.

25. Bouillanne O, Neveux N, Nicolis I, Curis E, Cynober L, Aussel C. Long-lasting improved amino acid bioavailability associated with protein pulse feeding in hospitalized elderly patients: a randomized controlled trial. Nutrition. 2014;30(5):544-50.

26. Dardevet D, Sornet C, Balage M, Grizard J. Stimulation of muscle protein synthesis by leucine is decreased with age. Clinical Nutrition. 2000;19(suppl.):33-4.

27. Combaret L, Dardevet D, Rieu I, Pouch M-N, Béchet D, Taillandier D, et al. A leucinesupplemented diet restores the defective postprandial inhibition of proteasome-dependent proteolysis in aged rat skeletal muscle. Journal of Physiology. 2005;569(2):489-99.

28. Katsanos CS, Kobayashi H, Sheffield-Moore M, Aarsland A, Wolfe RR. A high proportion of leucine is required for optimal stimulation of the rate of muscle protein synthesis by essential amino acids in the elderly. American Journal of Physiology-Endocrinology and Metabolism. 2006;291(2):E381-E7.

29. Guillet C, Zangarelli A, Mishellany A, Rousset P, Sornet C, Dardevet D, et al. Mitochondrial and sarcoplasmic proteins, but not myosin heavy chain, are sensitive to leucine supplementation in old rat skeletal muscle. Experimental Gerontology. 2004;39(5):745-51.

30. Balage M, Dardevet D. Long-term effects of leucine supplementation on body composition. Curr Opin Clin Nutr Metab Care. 2010;13(3):265-70.

31. Rieu I, Balage M, Sornet C, Giraudet C, Pujos E, Grizard J, et al. Leucine supplementation improves muscle protein synthesis in elderly men independently of hyperaminoacidaemia. The Journal of Physiology. 2006;575(Pt 1):305-15.

32. Dreyer HC, Drummond MJ, Pennings B, Fujita S, Glynn EL, Chinkes DL, et al. Leucineenriched essential amino acid and carbohydrate ingestion following resistance exercise enhances mTOR signaling and protein synthesis in human muscle. Am J Physiol Endocrinol Metab. 2008;294(2):E392-400.

33. Verhoeven S, Vanschoonbeek K, Verdijk LB, Koopman R, Wodzig WKWH, Dendale P, et al. Long-term leucine supplementation does not increase muscle mass or strength in healthy elderly men. The American Journal of Clinical Nutrition. 2009;89(5):1468-75.

34. Zeanandin G, Balage M, Schneider SM, Dupont J, Hébuterne X, Mothe-Satney I, et al. Differential effect of long-term leucine supplementation on skeletal muscle and adipose tissue in old rats: an insulin signaling pathway approach. AGE. 2012;34(2):371-87.

35. Dangin M, Boirie Y, Guillet C, Beaufrère B. Influence of the protein digestion rate on protein turnover in young and elderly subjects. J Nutr. 2002;132(10):3228s-33s.

36. Pennings B, Boirie Y, Senden JM, Gijsen AP, Kuipers H, van Loon LJ. Whey protein stimulates postprandial muscle protein accretion more effectively than do casein and casein hydrolysate in older men. Am J Clin Nutr. 2011;93(5):997-1005.

37. Rieu I, Balage M, Sornet C, Debras E, Ripes S, Rochon-Bonhomme C, et al. Increased availability of leucine with leucine-rich whey proteins improves postprandial muscle protein synthesis in aging rats. Nutrition. 2007;23(4):323-31. 
38. Mosoni L, Gatineau E, Gatellier P, Migné C, Savary-Auzeloux I, Rémond D, et al. High Whey Protein Intake Delayed the Loss of Lean Body Mass in Healthy Old Rats, whereas Protein Type and Polyphenol/Antioxidant Supplementation Had No Effects. Plos One. 2014;9(9):11 p. 39. Magne H, Auzeloux I, Migne C, Peyron M-A, Combaret L, Remond D, et al. Contrarily to whey and high protein diets, dietary free leucine supplementation cannot reverse the lack of recovery of muscle mass after prolonged immobilization during ageing. Journal of Physiology. 2012;590(8):2035-49.

40. Magne H, Savary-Auzeloux I, Rémond D, Dardevet D. Nutritional strategies to counteract muscle atrophy caused by disuse and to improve recovery. Nutrition Research Reviews. 2013;26(2):149-65.

41. Hubbard GP, Elia M, Holdoway A, Stratton RJ. A systematic review of compliance to oral nutritional supplements. Clin Nutr. 2012;31(3):293-312.

42. Reeds PJ, M.F. Fuller, and B.A. Nicholson. . Metabolic basis of energy expenditure with particular reference to protein. in Substrate and Energy Metabolism in Man, J S Garrow, editor; and D Halliday, editor, eds London: John Libby

1985:46-7

43. Waterlow JC, and Millward, D. J. Energy cost of turnover of protein and other cellular constituents. in Energy Transformations in Cells and Organisms, W Wieser, editor; and E Gnaiger, editor, eds Stuttgart: Georg Thieme Verlag. 1989:277-82

44. Gatineau E, Polakof S, Dardevet D, Mosoni L. Similarities and interactions between the ageing process and high chronic intake of added sugars. Nutrition Research Reviews. 2017;30(2):191-207.

45. Gatineau E, Savary-Auzeloux I, Migne C, Polakof S, Dardevet D, Mosoni L. Chronic Intake of Sucrose Accelerates Sarcopenia in Older Male Rats through Alterations in Insulin Sensitivity and Muscle Protein Synthesis. Journal of Nutrition. 2015;145(5):923-30.

46. De Bandt JP, Jegatheesan P, Tennoune-El-Hafaia N. Muscle Loss in Chronic Liver Diseases: The Example of Nonalcoholic Liver Disease. Nutrients. 2018;10(9).

47. Laclaustra M, Rodriguez-Artalejo F, Guallar-Castillon P, Banegas JR, Graciani A, Garcia-Esquinas E, et al. Prospective association between added sugars and frailty in older adults. Am J Clin Nutr. 2018;107(5):772-9.

48. Revel A, Jarzaguet M, Peyron M-A, Papet I, Hafnaoui N, Migné C, et al. At same leucine intake, a whey/plant protein blend is not as effective as whey to initiate a transient post prandial muscle anabolic response during a catabolic state in mini pigs. PLOS ONE. 2017;12(10):e0186204.

49. Choudry HA, Pan M, Karinch AM, Souba WW. Branched-Chain Amino Acid-Enriched Nutritional Support in Surgical and Cancer Patients. The Journal of Nutrition. 2006;136(1):314S$8 \mathrm{~S}$.

50. Nicastro H, Zanchi NE, da Luz CR, de Moraes WMAM, Ramona P, de Siqueira Filho MA, et al. Effects of leucine supplementation and resistance exercise on dexamethasone-induced muscle atrophy and insulin resistance in rats. Nutrition. 2012;28(4):465 - 71.

51. Nicastro H, Artioli GG, dos Santos Costa A, Solis MY, da Luz CR, Blachier F, et al. An overview of the therapeutic effects of leucine supplementation on skeletal muscle under atrophic conditions. Amino Acids. 2011;40(2):287-300.

52. Lacroix M, Bos C, Léonil J, Airinei G, Luengo C, Daré S, et al. Compared with casein or total milk protein, digestion of milk soluble proteins is too rapid to sustain the anabolic 
postprandial amino acid requirement. The American Journal of Clinical Nutrition. 2006;84(5):1070-9.

53. Atherton PJ, Etheridge T, Watt PW, Wilkinson D, Selby A, Rankin D. Muscle full effect after oral protein: time-dependent concordance and discordance between human muscle protein synthesis and mTORC1 signaling. Am J Clin Nutr. 2010;92.

54. Bohé J, Low JFA, Wolfe RR, Rennie MJ. Latency and duration of stimulation of human muscle protein synthesis during continuous infusion of amino acids. The Journal of Physiology. 2001;532(2):575-9.

55. Norton LE, Layman DK, Bunpo P, Anthony TG, Brana DV, Garlick PJ. The Leucine Content of a Complete Meal Directs Peak Activation but Not Duration of Skeletal Muscle Protein Synthesis and Mammalian Target of Rapamycin Signaling in Rats. The Journal of Nutrition. 2009;139(6):1103-9.

56. Wilson GJ, Layman DK, Moulton CJ, Norton LE, Anthony TG, Proud CG, et al. Leucine or carbohydrate supplementation reduces AMPK and eEF2 phosphorylation and extends postprandial muscle protein synthesis in rats. American Journal of Physiology - Endocrinology And Metabolism. 2011;301(6):E1236-E42.

57. Mosoni L, Jarzaguet M, David J, Polakof S, Savary-Auzeloux I, Remond D, et al. Post Meal Energy Boluses Do Not Increase the Duration of Muscle Protein Synthesis Stimulation in Two Anabolic Resistant Situations. Nutrients. 2019;11(4).

58. Meek SE, Persson M, Ford GC, Nair KS. Differential regulation of amino acid exchange and protein dynamics across splanchnic and skeletal muscle beds by insulin in healthy human subjects. 1998;47(12):1824-35.

59. Snijders T, Trommelen J, Kouw IWK, Holwerda AM, Verdijk LB, van Loon LJC. The Impact of Pre-sleep Protein Ingestion on the Skeletal Muscle Adaptive Response to Exercise in Humans: An Update. Front Nutr. 2019;6:17.

60. Karagounis LG, Beaumont M, Donato-Capel L, Godin JP, Kapp AF, Draganidis D, et al. Ingestion of a Pre-bedtime Protein Containing Beverage Prevents Overnight Induced Negative Whole Body Protein Balance in Healthy Middle-Aged Men: A Randomized Trial. Front Nutr. 2019;6:181.

61. Beelen M, Tieland M, Gijsen AP, Vandereyt H, Kies AK, Kuipers H, et al. Coingestion of carbohydrate and protein hydrolysate stimulates muscle protein synthesis during exercise in young men, with no further increase during subsequent overnight recovery. J Nutr. 2008;138(11):2198-204.

62. Pedersen JH, Alnor D, Vilstrup H, Hansen BA. Effect of fructose on the capacity of ureaN synthesis in rats. Clin Nutr. 1994;13(4):243-6.

63. Takada R, Saitoh M. Consumption of carbohydrate or medium- or long-chain triglycerides by unfed rats exerts different protein-sparing effects. J Nutr. 1995;125(8):2165-71. 64. Levine S, Saltzman A. Feeding sugar overnight maintains metabolic homeostasis in rats and is preferable to overnight starvation. Lab Anim. 2000;34(3):301-6.

65. Cuthbertson DP, Munro HN. The relationship of carbohydrate metabolism to protein metabolism: The roles of total dietary carbohydrate and of surfeit carbohydrate in protein metabolism. Biochem J. 1939;33(1):128-42.

66. Gamble JL. Physiological information gained from studies on the life raft ration. Harvey Lect. 1947;42:247-73.

67. Gelfand RA, Sherwin RS. Nitrogen conservation in starvation revisited: protein sparing with intravenous fructose. Metabolism. 1986;35(1):37-44. 
68. Fukagawa NK, Veirs H, Langeloh G. Acute effects of fructose and glucose ingestion with and without caffeine in young and old humans. Metabolism. 1995;44(5):630-8.

69. Wilmore DW. Postoperative protein sparing. World J Surg. 1999;23(6):545-52.

70. Mikura MSM, Yamaoka PDI, Doi PDM, Kawano PDY, Nakayama PDM, Nakao MSR, et al. Glucose infusion suppresses surgery-induced muscle protein breakdown by inhibiting ubiquitin-proteasome pathway in rats. Anesthesiology. 2009;110(1):81-8.

71. Boirie Y, Walrand S, Beaufrere B. Control of amino acid metabolism by lipids, ketone bodies and glucose substrates. In: Cynober L, editor. Metabolic and Therapeutic Aspects of Amino Acids in Clinical Nutrition. 2 ed: CRC Press; 2003.

72. Lustig RH. Fructose: it's "alcohol without the buzz". Adv Nutr. 2013;4(2):226-35.

73. Dardevet D, Mosoni L, David J, Polakof S. Fructose feeding during the postabsorptive state alters body composition and spares nitrogen in protein-energy-restricted old rats. J Nutr. 2018;148(1):40-8.

74. Bouillanne O, Dupont-Belmont C, Hay P, Hamon-Vilcot B, Cynober L, Aussel C. Fat mass protects hospitalized elderly persons against morbidity and mortality. Am J Clin Nut. 2009;90(3):505-10.

75. Hickson M. Malnutrition and ageing. Postgrad Med J. 2006;82(963):2-8.

76. Peyron MA, Woda A, Bourdiol P, Hennequin M. Age-related changes in mastication. J Oral Rehabil. 2017;44(4):299-312.

77. Rémond D, Shahar DR, Gille D, Pinto P, Kachal J, Peyron MA, et al. Understanding the gastrointestinal tract of the elderly to develop dietary solutions that prevent malnutrition. Oncotarget. 2015;6(16):13858-98.

78. Lamster IB, Asadourian L, Del Carmen T, Friedman PK. The aging mouth: differentiating normal aging from disease. Periodontol 2000. 2016;72(1):96-107.

79. Yoshida M, Kazuhiro T. Sarcopenia and mastication. Current Oral Health Report. 2020;7:179-87.

80. Peyron MA, Santé-Lhoutellier V, François O, Hennequin M. Oral declines and mastication deficiencies cause alteration of food bolus properties. Food Funct. 2018;9(2):111222.

81. Mishellany-Dutour A, Renaud J, Peyron MA, Rimek F, Woda A. Is the goal of mastication reached in young dentates, aged dentates and aged denture wearers? The British journal of nutrition. 2008;99(1):121-8.

82. Watanabe Y, Hirano H, Arai H, Morishita S, Ohara Y, Edahiro A, et al. Relationship Between Frailty and Oral Function in Community-Dwelling Elderly Adults. Journal of the American Geriatrics Society. 2017;65(1):66-76.

83. Horibe Y, Ueda T, Watanabe Y, Motokawa K, Edahiro A, Hirano H, et al. A 2-year longitudinal study of the relationship between masticatory function and progression to frailty or pre-frailty among community-dwelling Japanese aged 65 and older. J Oral Rehabil. 2018;45(11):864-70.

84. O'Keeffe M, Kelly M, O'Herlihy E, O'Toole PW, Kearney PM, Timmons S, et al. Potentially modifiable determinants of malnutrition in older adults: A systematic review. Clin Nutr. 2019;38(6):2477-98.

85. Marcenes W, Steele JG, Sheiham A, Walls AW. The relationship between dental status, food selection, nutrient intake, nutritional status, and body mass index in older people. Cad Saude Publica. 2003;19(3):809-16.

86. Joshipura KJ, Willett WC, Douglass CW. The impact of edentulousness on food and nutrient intake. J Am Dent Assoc. 1996;127(4):459-67. 
87. Sheiham A, Steele JG, Marcenes W, Lowe C, Finch S, Bates CJ, et al. The relationship among dental status, nutrient intake, and nutritional status in older people. Journal of dental research. 2001;80(2):408-13.

88. Mioche L, Bourdiol P, Peyron MA. Influence of age on mastication: effects on eating behaviour. Nutr Res Rev. 2004;17(1):43-54.

89. Remond D, Machebeuf M, Yven C, Buffiere C, Mioche L, Mosoni L, et al. Postprandial whole-body protein metabolism after a meat meal is influenced by chewing efficiency in elderly subjects. American Journal of Clinical Nutrition. 2007;85(5):1286-92.

90. Aguilera JM, Park DJ. Texture-modified foods for the elderly: Status, technology and opportunities. Trends in Food Science \& Technology. 2016;57:156-64.

91. Pennings B, Groen BB, van Dijk JW, de Lange A, Kiskini A, Kuklinski M, et al. Minced beef is more rapidly digested and absorbed than beef steak, resulting in greater postprandial protein retention in older men. The American journal of clinical nutrition. 2013;98(1):121-8. 92. Kikutani T, Enomoto R, Tamura F, Oyaizu K, Suzuki A, Inaba S. Effects of oral functional training for nutritional improvement in Japanese older people requiring long-term care. Gerodontology. 2006;23(2):93-8.

93. Calvez J, Benoit S, Fleury L, Khodorova N, Piedcoq J, Tomé D, et al. True Ileal Protein Digestibility of Zein and Whey Protein Isolate in Healthy Humans (OR27-06-19). Current Developments in Nutrition. 2019;3(Supplement_1).

94. Matthews LB, Kunkel ME, Acton JC, Ogale AA, Dawson PL. Bioavailability of Soy Protein and Corn Zein Films. Food and Nutrition Sciences. 2011;Vol.02No.10:9.

95. Caine WR, Sauer WC, Verstegen MW, Tamminga S, Li S, Schulze H. Guanidinated protein test meals with higher concentration of soybean trypsin inhibitors increase ileal recoveries of endogenous amino acids in pigs. The Journal of nutrition. 1998;128(3):598-605.

96. Dufour C, Loonis M, Delosiere M, Buffiere C, Hafnaoui N, Sante-Lhoutellier V, et al. The matrix of fruit \& vegetables modulates the gastrointestinal bioaccessibility of polyphenols and their impact on dietary protein digestibility. Food chemistry. 2018;240:314-22.

97. Mosoni L, Balage M, Vazeille E, Combaret L, Morand C, Zagol-Ikapitte I, et al. Antioxidant supplementation had positive effects in old rat muscle, but through better oxidative status in other organs. Nutrition. 2010;26(11):1157-62.

98. Mosoni L, L., Gatineau E, E., Gatellier P, P., Migne C, C., Savary-Auzeloux I, Auzeloux, Remond D, D., et al. High Whey Protein Intake Delayed the Loss of Lean Body Mass in Healthy Old Rats, whereas Protein Type and Polyphenol/Antioxidant Supplementation Had No Effects. PLOS ONE. 2014;9(9):11 p.

99. Dangin M, Guillet C, Garcia-Rodenas C, Gachon P, Bouteloup-Demange C, ReiffersMagnani K, et al. The Rate of Protein Digestion affects Protein Gain Differently during Aging in Humans. The Journal of Physiology. 2003;549(2):635-44.

100. Bax M-L, Buffière C, Hafnaoui N, Gaudichon C, Auzeloux I, Dardevet D, et al. Effects of Meat Cooking, and of Ingested Amount, on Protein Digestion Speed and Entry of Residual Proteins into the Colon: A Study in Minipigs. Plos One. 2013;8(4).

101. Bax ML, Aubry L, Ferreira C, Daudin JD, Gatellier P, Rémond D, et al. Cooking temperature is a key determinant of in vitro meat protein digestion rate: investigation of underlying mechanisms. J Agric Food Chem. 2012;60(10):2569-76.

102. Oberli M, Marsset-Baglieri A, Airinei G, Santé-Lhoutellier V, Khodorova N, Rémond D, et al. High True Ileal Digestibility but Not Postprandial Utilization of Nitrogen from Bovine Meat Protein in Humans Is Moderately Decreased by High-Temperature, Long-Duration Cooking. J Nutr. 2015;145(10):2221-8. 
103. Buffière C, Gaudichon C, C., Hafnaoui N, Migne C, C., Scislowsky V, Khodorova N, et al. In the elderly, meat protein assimilation from rare meat is lower than that from meat that is well done. American Journal of Clinical Nutrition. 2017;106(5):1257-66.

104. Barbé F, Ménard O, Le Gouar Y, Buffière C, Famelart M-H, Laroche B, et al. The heat treatment and the gelation are strong determinants of the kinetics of milk proteins digestion and of the peripheral availability of amino acids. Food Chemistry. 2013;136(3-4):1203-12.

105. Barbé F, Ménard O, Gouar YL, Buffière C, Famelart M-H, Laroche B, et al. Acid and rennet gels exhibit strong differences in the kinetics of milk protein digestion and amino acid bioavailability. Food Chemistry. 2014;143:1-8.

106. Gaudichon C, Roos N, Mahé S, Sick H, Bouley C, Tomé D. Gastric emptying regulates the kinetics of nitrogen absorption from $15 \mathrm{~N}$-labeled milk and $15 \mathrm{~N}$-labeled yogurt in miniature pigs. J Nutr. 1994;124(10):1970-7.

107. DGA. Committee DGAC. Report of the Dietary Guidelines Advisory Committee on the Dietary Guidelines for Americans, to the Secretary of Agriculture and the Secretary of Health and Human Services. US Government Printing Office, Washington, DC, USA, . 2010.

108. Boland MJ, Rae AN, Vereijken JM, Meuwissen MPM, Fischer ARH, van Boekel MAJS, et al. The future supply of animal-derived protein for human consumption. Trends in Food Science \& Technology. 2013;29(1):62-73.

109. De Gavelle E, Davidenko O, Fouillet H, Delarue J, Darcel N, Huneau JF, et al. Selfdeclared attitudes and beliefs regarding protein sources are a good prediction of the degree of transition to a low-meat diet in France. Appetite. 2019;142:104345.

110. Mariotti F, Gardner CD. Dietary Protein and Amino Acids in Vegetarian Diets-A Review. Nutrients. 2019;11(11).

111. Organization FA. The state of food insecurity in the world. fao Rome; 2015.

112. Organization WH. Protein quality evaluation: report of the Joint FAO/WHO Expert

Consultation, Bethesda, Md., USA, 4-8 December 1989. Protein quality evaluation: report of the

Joint FAO/WHO Expert Consultation, Bethesda, Md, USA, 4-8 December 19891991.

113. Sands DC, Morris CE, Dratz EA, Pilgeram A. Elevating optimal human nutrition to a central goal of plant breeding and production of plant-based foods. Plant Sci. 2009;177(5):37789.

114. Gorissen SH, Horstman AM, Franssen R, Crombag JJ, Langer H, Bierau J, et al. Ingestion of Wheat Protein Increases In Vivo Muscle Protein Synthesis Rates in Healthy Older Men in a Randomized Trial. The Journal of Nutrition. 2016;146(9):1651-9.

115. Berrazaga I, Salles J, Laleg K, Guillet C, Patrac V, Giraudet C, et al. Anabolic Properties of Mixed Wheat-Legume Pasta Products in Old Rats: Impact on Whole-Body Protein Retention and Skeletal Muscle Protein Synthesis. Nutrients. 2020;12(6).

116. Jarzaguet M, Polakof S, David J, Migné C, Joubrel G, Efstathiou T, et al. A meal with mixed soy/whey proteins is as efficient as a whey meal in counteracting the age-related muscle anabolic resistance only if the protein content and leucine levels are increased. Food \& Function. 2018;9(12):6526-34.

117. van Vliet S, Burd NA, van Loon LJ. The Skeletal Muscle Anabolic Response to Plantversus Animal-Based Protein Consumption. J Nutr. 2015;145(9):1981-91.

118. Nikita V. Alexandrov CE, Cécile M. Singh-Povel, Gerjan J. Navis, Stephan J. L. Bakker, Eva Corpeleijn. Dietary Protein Sources and Muscle Mass over the Life Course: The Lifelines Cohort Study. Nutrients. 2018;10(10):1471. 
119. Lonnie M, Hooker E, Brunstrom JM, Corfe BM, Green MA, Watson AW, et al. Protein for Life: Review of Optimal Protein Intake, Sustainable Dietary Sources and the Effect on Appetite in Ageing Adults. Nutrients. 2018;10(3).

120. de Gavelle E, Huneau JF, Bianchi CM, Verger EO, Mariotti F. Protein Adequacy Is Primarily a Matter of Protein Quantity, Not Quality: Modeling an Increase in Plant:Animal Protein Ratio in French Adults. Nutrients. 2017;9(12). 


\section{Figure legends}

Figure 1: Schematic representation of the quality of a dietary protein according to its amino acid (AA) composition and to the target population. The vertical bar represents the AA and the height of the bar represents the amount of the amino acid present in the protein ingested as a percentage of the minimum requirement value of the population mentioned and when consumed at the amount specified in the graph (derived from the FAO. If the height of the bar is below the minimal requirement $(100 \%)$ then the corresponding AA is considered as limiting. Couple by Akshar Pathak from the Noun Project; Couple by Gan Khoon Lay from the Noun Project ; Fat man by Gan Khoon Lay from the Noun Project; sick by Gan Khoon Lay from the Noun Project

Figure 2: Example of meals given for breakfast, lunch and diner with a "protein pulse feeding" protocol in the study of Arnal et al. (23)( personal communication) Breakfast by Agung Cahyo; Breakfast by rahmat from the Noun Project

Figure 3: Schematic representation of the metabolic pathways involved between the different organs in a night-fasting situation with or without a fructose bolus given apart from dinner and just before bedtime. The thickness of the arrow represents either the amount of the nutrient involved or the intensity of the corresponding metabolic pathway. The number represents the order in which the nutrient flows are involved. Gut, liver by Philip Hogeboom; Muscle by Adrien Coquet from the Noun Project

Figure 4: Effect of masticatory deficiency on plasma amino acid availability and whole body anabolic effect (from Rémond et al. 2007) (89) Denture by Jems Mayor; Teeth by Adrien Coquet; Steak by Sandra from the Noun Project

Figure 5: Schematic representation of the plasma kinetic of amino acid appearance, digestion speed and maximal plasma amino acid levels following the same amount of slow and fast digested dietary proteins with identical digestibility. 


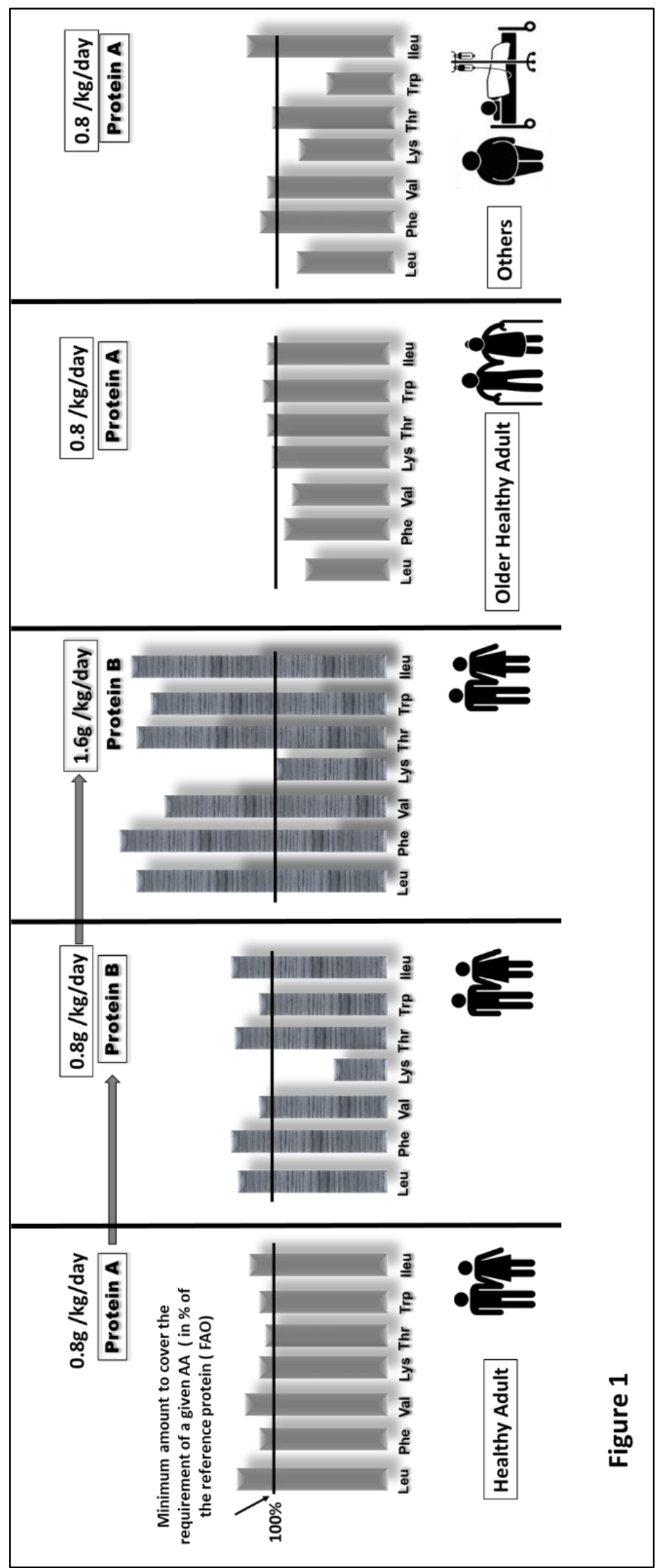




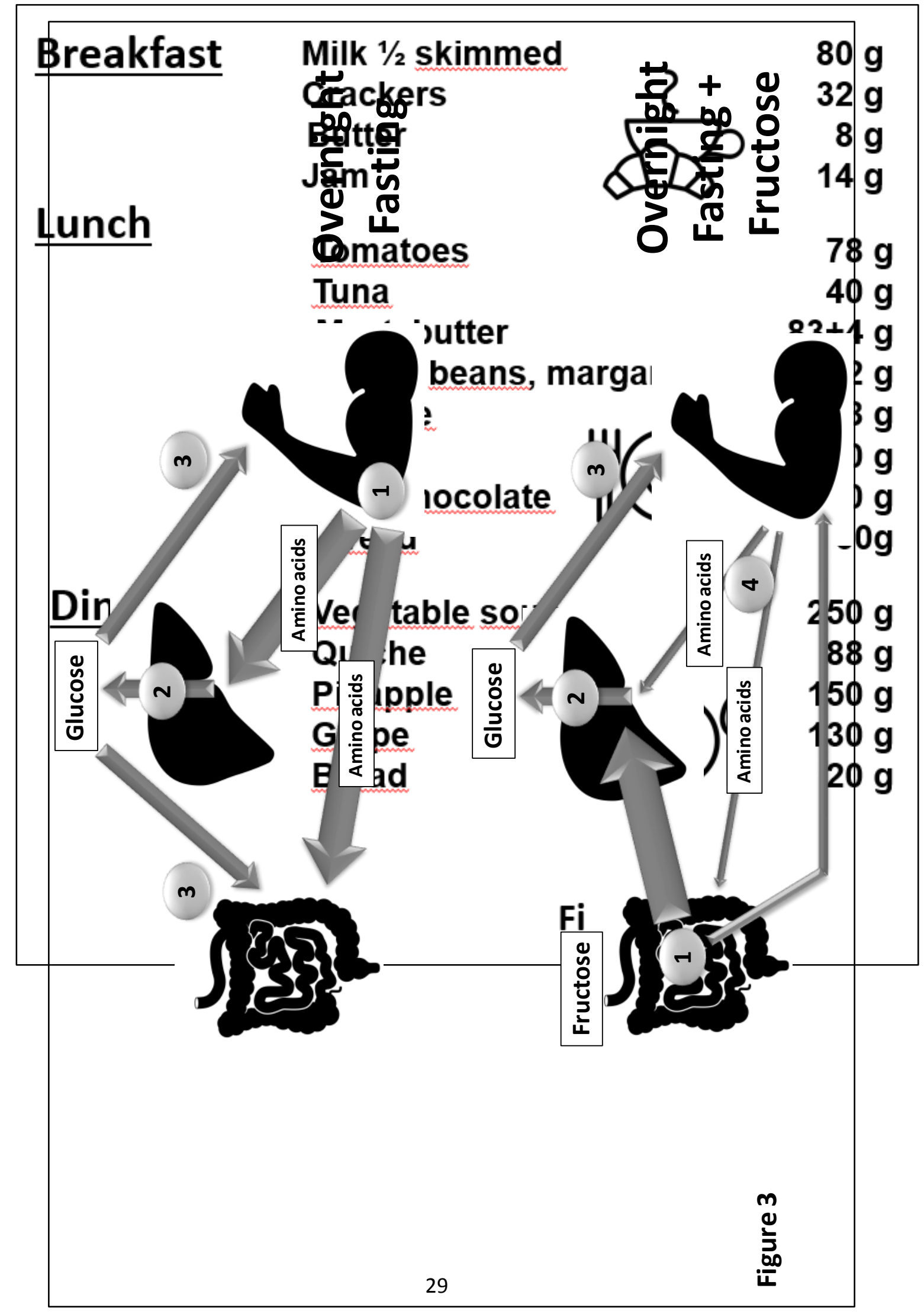




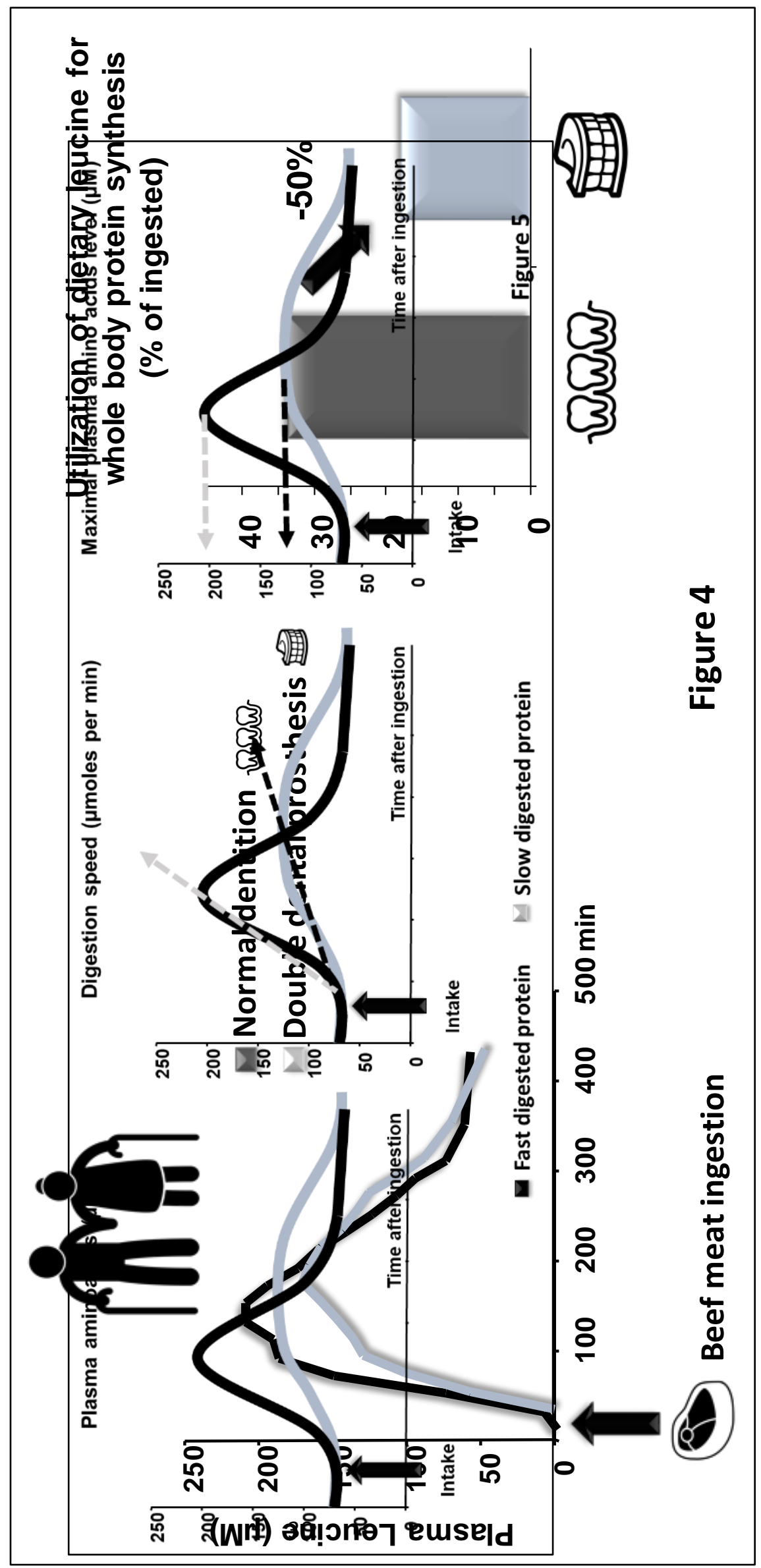

